\title{
When the Tomb Owner offers to Parents and Relatives in Theban private Tombs
}

\author{
Abdel-Azem Kamel Soliman $^{\text {a }} \quad$ Haitham T. A. Sotohy ${ }^{b}$, \\ a PhD Researcher, Tourist Guidance Department, Faculty of Tourism and Hotels, Minia University, Egypt. \\ b Assistant Professor, EGOTH Institute for Tourism and Hotels, Luxor, Egypt
}

\section{Keywords}

Offering

Tomb owner

Eldest son

Parents

Relatives

\begin{abstract}
The New Kingdom's private tombs in Thebes contain some scenes that represent the tomb owner presenting offerings to parents, brothers, grandparents, viziers and others. This research study this topic through some scenes to resolve its ambiguity, as it is known that the tomb owner, as deceased on his tomb, is supposed to be the receiver of offerings from others and not the opposite. This study collects and categorizes all these scenes with brief description in its "Table of scenes". The study deals, in more detail, with six scenes in an attempt to present an interpretation that can be applied to the rest of the scenes. The study interprets the representations and associated texts of the six scenes and sometimes uses the "Table of scenes" for enumeration and when needed. The study also examines the condition and the appearance of the tomb owner on the scenes, does he represent himself alive or dead? The study deals with the meaning of the sentence "who revives his / your name" or the so called vivification formula on the offering texts. For more clarification, the study deals with the responsibility of living to revive the dead's names, the effect of that on the dead, and the award of the person responsible for reviving the dead's name. The study referred to the subjects of offering scenes as piety towards parents, ancestor's cult and using these scenes as a way of thanksgiving for the favor.
\end{abstract}




\section{Introduction:}

The decorative program of funerary practices displayed inside the Theban private tombs is developed during the new kingdom such as others architectural elements of this period (Abdul-Qader , 1966) . The theme of the offering scenes has remained stable within the tombs with some changes. Offerings to the dead are known from prehistoric times. The ancient Egyptian represented these offerings scenes in tombs in the form of food, drinks and clothes and others kinds.

Offerings to the dead are seen depicted several times in New kingdom, on the walls of every tomb. (Abdul-Qader , 1966) According to the thought ancient Egyptian, the offerings to the dead were intended for the restoration of life (Donald, 2001), the dead becomes in a state of temporary sleeping after death, and in order to be able to restore his activity, the living must be offered all good and pure offerings which are proper for those who entered the divine world". ${ }^{1}$

These practices started since the Old Kingdom, a group of inscriptions called "Appeal to the Living" in the Old Kingdom private tombs showed this connection between living and dead, it mentioned also the provision of offerings by the ka-priests as well as other people. It began in the Fifth Dynasty and remained popular until the Late Period (Jing , 2018)

The living offered to the dead in the vicinity of their tombs to ensure protection of gods and blessed status in the afterlife for the deceased (Harrington, 2018) This connection between the living and dead was based largely on the principal of reciprocity, the living provided for the deceased in the tomb in exchange for the deceased to protect the living in his life or even stop his evil against them.

During the new Kingdom, some offering scenes contradicted these inherited arrangement of traditions. A number of scenes appeared in Theban private tombs represent the owner of the tomb offers to other individuals, mostly relatives(AbdulQader, 1966).

A collection of at least 44 scenes were mentioned in Porter and Moss represented the deceased offers to his relatives in his own tomb (Porter et al , 1971). The parents or one of them shared receiving offering from the tomb owner in 24 times. The offering scenes to the parents are more than the sum of all other scenes ${ }^{2}$. These offering scenes to parents are only a collection of a greater number of scenes that represented the parents inside the tombs of their sons in a position of honor and respect. In an earlier study of Whale (Whale , 1989) it was proved that both parents of the tomb owner were represented in fifty-two tombs.

\section{The scenes of offerings presented by the tomb owner:}

The offerings scenes which represented the tomb owner offering to his parents and ancestors, were occurred in tombs TT 2(P.M No.4),TT 15(P.M No6.), TT 17(P.M No.3), TT 18(P.M No.4), TT 23(P.M No.33,34), TT 45(P.M No.6), TT 64(P.M No.7), TT 82(P.M No.4), TT 93(P.M No.16), TT 96(P.M No.22), TT 111(P.M No.3), TT 112(P.M No.5), TT 122(P.M No.5), TT 127(P.M No.16), TT 139(P.M No.3), TT 148(P.M No.2), TT 181(P.M No.7), TT 194(P.M No.5), TT 279(P.M No.8,13), TT 290(P.M No.2), TT 291(P.M No.4), TT 295(P.M No.4), TT 330(P.M No.2), TT

\footnotetext{
${ }^{1}$ Redford,.565.

${ }^{2}$ This classification of offering scenes to the parents is according to the list on PM, 480.
} 
335(P.M No.10) and TT 345(P.M No.6). Other scenes which represented the tomb owner offering to brothers, relatives of holy titles, friends, co-workers and men of authority, were occurred in tombs TT 22(P.M No.33, 34), TT 52(P.M No.6), TT82 twice (PM I, no. 3, 6), TT 85(P.M No.16, B, C), TT 96(P.M No.12), TT 122(P.M No.5). TT 148 (PM No.2), TT 183(P.M No.14), TT 194(P.M No.5), TT 194(P.M No.5), TT 290(P.M No.2), TT 330(P.M No.2), TT 335(P.M No.16) and TT 345(P.M No.6). ${ }^{3}$

\subsection{Table of scenes: Offering scenes from the tomb owner to his relatives.}

\subsubsection{Scenes from the 18th Dynasty}

Table (1) Scenes from the 18th Dynasty

\begin{tabular}{|c|c|c|c|c|c|}
\hline Brief description & TT\&Owner & Date & Location & $\begin{array}{l}\text { Place of } \\
\text { the } \\
\text { scene }\end{array}$ & PM, I. \\
\hline $\begin{array}{c}\text { 1: The Deceased } \\
\text { (T.O) Tetaky, } \\
\text { Offers to his } \\
\text { Parents, Rahotep } \\
\text { and Sensonb. }\end{array}$ & 15: Tetaky. & $\begin{array}{l}18^{\text {th }} \text { D., } \\
\text { Ahmose. }\end{array}$ & $\begin{array}{c}\text { Dra Abul- } \\
\text { Naga. }\end{array}$ & $\begin{array}{l}\text { Interior } \\
\text { chapel, } \\
\text { west wall. }\end{array}$ & (6) p.27 \\
\hline $\begin{array}{l}\text { 2: The Deceased } \\
\text { (T.O) Amenhotep } \\
\text { offers to his parents } \\
\text { Sntydjhout and } \\
\text { Taghred. }\end{array}$ & 345: Amenhotep. & $\begin{array}{l}\text { 18th D., } \\
\text { Tuthmosis } \\
\text { I. }\end{array}$ & $\begin{array}{l}\text { Shekh Abd } \\
\text { el-Qurna. }\end{array}$ & $\begin{array}{l}\text { Hall, } \\
\text { notrth } \\
\text { wall, east } \\
\text { half. }\end{array}$ & (6), p.414. \\
\hline $\begin{array}{l}\text { 3: The Deceased } \\
\text { (T.O) Amenhotep } \\
\text { offers to his brother } \\
\text { Neferhotep and his } \\
\text { wife. }\end{array}$ & 345: Amenhotep & $\begin{array}{c}\text { 18th D., } \\
\text { Tuthmosis } \\
\text { I. }\end{array}$ & $\begin{array}{l}\text { Shekh Abd } \\
\text { el-Qurna. }\end{array}$ & $\begin{array}{c}\text { Hall, } \\
\text { notrth } \\
\text { wall, west } \\
\text { half. }\end{array}$ & (6), p.414. \\
\hline $\begin{array}{c}\text { 4: The Deceased } \\
\text { (T.O) Senemiah } \\
\text { offers to his } \\
\text { ancestors (father and } \\
\text { father's mother). }\end{array}$ & 127 of Senemiah. & $\begin{array}{l}18^{\text {th }} \text { D., } \\
\text { Thoutmosis } \\
\text { III. }\end{array}$ & $\begin{array}{l}\text { Shekh Abd } \\
\text { el-Qurna. }\end{array}$ & $\begin{array}{l}\text { The outer } \\
\text { lintel of } \\
\text { the inner } \\
\text { room. }\end{array}$ & (16) P.243 \\
\hline $\begin{array}{c}\text { 5: The Deceased } \\
\text { (T.O) Amenemhet } \\
\text { Offers to his } \\
\text { Ancestors. }\end{array}$ & 82: Amenemhet & $\begin{array}{c}18^{\text {th }} \text { D., } \\
\text { Tuthmosis } \\
\text { III }\end{array}$ & $\begin{array}{l}\text { Shekh Abd } \\
\text { el-Qurna. }\end{array}$ & $\begin{array}{l}\text { Hall, left } \\
\text { wall. }\end{array}$ & (4) p.164 \\
\hline $\begin{array}{l}\text { 6: The Deceased } \\
\text { (T.O) Amenemhet }\end{array}$ & 82: Amenemhet & $\begin{array}{c}18^{\text {th }} \text { D., } \\
\text { Tuthmosis } \\
\text { III }\end{array}$ & $\begin{array}{l}\text { Shekh Abd } \\
\text { el-Qurna. }\end{array}$ & $\begin{array}{l}\text { Hall, east } \\
\text { wall, } \\
\text { southern }\end{array}$ & (6) p.164 \\
\hline
\end{tabular}

${ }^{3}$ P.M, I, 470 


\begin{tabular}{|c|c|c|c|c|c|}
\hline Brief description & TT\&Owner & Date & Location & $\begin{array}{c}\text { Place of } \\
\text { the } \\
\text { scene }\end{array}$ & PM, I. \\
\hline $\begin{array}{l}\text { offers to the Vizier } \\
\text { User and his wife } \\
\text { Thuiu. }\end{array}$ & & & & half. & \\
\hline $\begin{array}{c}\text { 7: The Deceased } \\
\text { (T.O) Amenemhet } \\
\text { offers to the Vizier } \\
\text { Iahmes. }\end{array}$ & 82 of Amenemhet & $\begin{array}{c}18^{\text {th }} \text { D., } \\
\text { Tuthmosis } \\
\text { III }\end{array}$ & $\begin{array}{l}\text { Shekh Abd } \\
\text { el-Qurna. }\end{array}$ & $\begin{array}{l}\text { Hall, east } \\
\text { wall. }\end{array}$ & (6) p.164. \\
\hline $\begin{array}{l}\text { 8: The Deceased } \\
\text { (T.O) Amenemhet } \\
\text { offers to the } \\
\text { architect and artists. }\end{array}$ & 82: Amenemhet & $\begin{array}{c}18^{\text {th }} \text { D., } \\
\text { Tuthmosis } \\
\text { III }\end{array}$ & $\begin{array}{c}\text { Shekh Abd } \\
\text { el-Qurna. }\end{array}$ & $\begin{array}{l}\text { Hall, left } \\
\text { wall. }\end{array}$ & (4) P.164. \\
\hline $\begin{array}{c}\text { 9: The Deceased } \\
\text { Baki (T.O)offers to } \\
\text { his parents. }\end{array}$ & 18: Baki. & $\begin{array}{l}18^{\text {th }} \text { D., } \\
\text { Tuthmosis } \\
\text { III }\end{array}$ & $\begin{array}{l}\text { Dra Abu } \\
\text { el-Naga. }\end{array}$ & Hall, & (4), p.32 \\
\hline $\begin{array}{c}\text { 10: The (T.O) } \\
\text { Menkheperrasonb } \\
\text { offers to his } \\
\text { maternal } \\
\text { grandparents Hepu } \\
\text { and Nebta. }\end{array}$ & $\begin{array}{c}112: \\
\text { Menkheperrasonb. }\end{array}$ & $\begin{array}{c}18^{\text {th }} \text { D., } \\
\text { Tuthmosis } \\
\text { III }\end{array}$ & $\begin{array}{c}\text { Shekh Abd } \\
\text { el-Qurna }\end{array}$ & $\begin{array}{l}\text { Hall, west } \\
\text { wall, left } \\
\text { part. }\end{array}$ & (5) P.230. \\
\hline $\begin{array}{l}\text { 11: The Deceased( } \\
\text { T.O) Amenemhab } \\
\text { offers to his wife } \\
\text { Baki while suckling } \\
\text { a prince. }\end{array}$ & $\begin{array}{l}\text { 85: Amenemhab } \\
\text { called Mahu. }\end{array}$ & $\begin{array}{c}18^{\text {th }} \text { D., } \\
\text { Tuthmosis } \\
\text { III }\end{array}$ & $\begin{array}{c}\text { Shekh Abd } \\
\text { el-Qurna }\end{array}$ & $\begin{array}{l}\text { Hall, north } \\
\text { wall }\end{array}$ & $\begin{array}{l}(16) \\
\text { p.172. }\end{array}$ \\
\hline $\begin{array}{c}\text { 12: The } \\
\text { Deceased(T.O) } \\
\text { Amenemhab offers } \\
\text { to his wife Baki } \\
\text { while suckling a } \\
\text { prince. }\end{array}$ & $\begin{array}{l}\text { 85: Amenemhab } \\
\text { called Mahu. }\end{array}$ & $\begin{array}{c}18^{\text {th }} \text { D., } \\
\text { Tuthmosis } \\
\text { III }\end{array}$ & $\begin{array}{c}\text { Shekh Abd } \\
\text { el-Qurna }\end{array}$ & $\begin{array}{l}\text { Hall, pillar } \\
\text { (C). }\end{array}$ & (C), p.173 \\
\hline $\begin{array}{l}\text { 13: The Deceased( } \\
\text { T.O) Amenemhab } \\
\text { offers to his wife } \\
\text { Baki while suckling } \\
\text { a prince. }\end{array}$ & $\begin{array}{l}\text { 85: Amenemhab } \\
\text { called Mahu. }\end{array}$ & $\begin{array}{c}18^{\text {th }} \text { D., } \\
\text { Tuthmosis } \\
\text { III }\end{array}$ & $\begin{array}{c}\text { Shekh Abd } \\
\text { el-Qurna }\end{array}$ & $\begin{array}{l}\text { Hall, pillar } \\
\text { (B) }\end{array}$ & (B), p.173 \\
\hline $\begin{array}{l}\text { 14: Neferhotep, } \\
\text { brother and son } \\
\text { offer to his brother } \\
\text { the vizier User and }\end{array}$ & 122: Neferhotep & $\begin{array}{l}18^{\text {th }} \text { D., } \\
\text { Tuthmosis } \\
\text { III. }\end{array}$ & $\begin{array}{l}\text { Shekh } \\
\text { Abdel- } \\
\text { Qurna. }\end{array}$ & $\begin{array}{l}\text { Corridor, } \\
\text { north wall, } \\
\text { west end. }\end{array}$ & $\begin{array}{l}(5-I), \\
\text { p. } 235\end{array}$ \\
\hline
\end{tabular}




\begin{tabular}{|c|c|c|c|c|c|}
\hline Brief description & TT\&Owner & Date & Location & $\begin{array}{c}\text { Place of } \\
\text { the } \\
\text { scene }\end{array}$ & PM, I. \\
\hline \multicolumn{6}{|l|}{ his wife. } \\
\hline $\begin{array}{l}\text { 15: Neferhotep } \\
\text { offers to his parents } \\
\text { the vizier Aametu } \\
\text { and his wife. }\end{array}$ & 122: Neferhotep & $\begin{array}{l}18^{\text {th }} \mathrm{D} . \\
\text { Tuthmosis } \\
\text { III. }\end{array}$ & $\begin{array}{l}\text { Shekh } \\
\text { Abdel- } \\
\text { Qurna. }\end{array}$ & $\begin{array}{l}\text { Corridor, } \\
\text { north wall, } \\
\text { west end. }\end{array}$ & $\begin{array}{l}\text { (5-I), } \\
\text { p. } 235\end{array}$ \\
\hline $\begin{array}{l}\text { 16: Sennefer offers } \\
\text { to his uncle the } \\
\text { mayor Humay and } \\
\text { his wife Nub. }\end{array}$ & TT 96 of Sennufer & $\begin{array}{l}\text { Amenophis } \\
\text { II }\end{array}$ & $\begin{array}{l}\text { Shekh Abd } \\
\text { el-Qurna }\end{array}$ & Inner Hall & (22),p.199. \\
\hline $\begin{array}{c}17: \text { Sennefer and } \\
\text { his wife offer to his } \\
\text { cousin Amenemopet } \\
\text { and his wife } \\
\text { (F.g.14). }\end{array}$ & TT 96 of Sennufer & $\begin{array}{l}\text { Amenophis } \\
\text { II }\end{array}$ & $\begin{array}{c}\text { Shekh Abd } \\
\text { el-Qurna }\end{array}$ & Passage & (12) p.198 \\
\hline $\begin{array}{l}18: \text { Kenamun offers } \\
\text { to his mother } \\
\text { Amenemopet } \\
\text { carrying Amenophis } \\
\text { II. }\end{array}$ & $\begin{array}{l}\text { TT } 93 \text { of } \\
\text { Kenamun }\end{array}$ & $\begin{array}{l}\text { Amenophis } \\
\text { II }\end{array}$ & $\begin{array}{l}\text { Shekh Abd } \\
\text { el-Qurna }\end{array}$ & Outer Hall & (16) P.192 \\
\hline $\begin{array}{l}19 \text { : Djehutemheb } \\
\text { offers to his parents } \\
\text { Wennefer and Isis. }\end{array}$ & TT 45 of Djhut & $\begin{array}{l}\text { Amenophis } \\
\text { II }\end{array}$ & $\begin{array}{l}\text { Shekh Abd } \\
\text { el-Qurna }\end{array}$ & Hall & (6), P.85 \\
\hline $\begin{array}{l}\text { 20: Nebamun offers } \\
\text { to his parents } \\
\text { Nebseny and } \\
\text { Hapynofret. }\end{array}$ & $\begin{array}{l}\text { TT } 17 \text { of } \\
\text { Nebamun }\end{array}$ & $\begin{array}{l}\text { Amenophis } \\
\text { II }\end{array}$ & $\begin{array}{l}\text { Dra Abu } \\
\text { el-Naga }\end{array}$ & Hall & (3) P.29 \\
\hline $\begin{array}{l}\text { 21: Kenamun offers } \\
\text { to his parents. }\end{array}$ & $\begin{array}{l}\text { TT } 162 \text { of } \\
\text { Kenamun }\end{array}$ & $\begin{array}{l}\text { Amenophis } \\
\text { II, } \\
\text { Tuhmosis } \\
\text { IV }\end{array}$ & $\begin{array}{l}\text { Dra Abu } \\
\text { el-Naga }\end{array}$ & $\begin{array}{l}\text { Thickness } \\
\text { passage }\end{array}$ & $\begin{array}{l}\text { No. (5) } \\
\text { P.276 }\end{array}$ \\
\hline $\begin{array}{l}22: \text { Hekerneheh } \\
\text { with princes offers } \\
\text { to his father the } \\
\text { royal tutor } \\
\text { Hekreshu. }\end{array}$ & $\begin{array}{l}\text { TT } 64 \text { of } \\
\text { Hekerneheh }\end{array}$ & $\begin{array}{l}\text { Tuhmosis } \\
\text { IV }\end{array}$ & $\begin{array}{l}\text { Shekh Abd } \\
\text { el-Qurna }\end{array}$ & Hall & (7) P.128 \\
\hline $\begin{array}{l}\text { 23: Djhutymes } \\
\text { (called Paroy) offers } \\
\text { to his grandparents } \\
\text { Sennetjer } \\
\text { and Senemiah with } \\
\text { small boy. }\end{array}$ & $\begin{array}{c}\text { TT } 295 \text { of } \\
\text { Dhutmosi called } \\
\text { Paroy }\end{array}$ & $\begin{array}{l}\text { Tuhmosis } \\
\text { IV - } \\
\text { Amenophis } \\
\text { III }\end{array}$ & El-khokha & $\begin{array}{l}\text { Hall, south } \\
\text { wall, east } \\
\text { part. }\end{array}$ & (4-I) P.377 \\
\hline
\end{tabular}




\begin{tabular}{|c|c|c|c|c|c|}
\hline Brief description & TT\&Owner & Date & Location & $\begin{array}{c}\text { Place of } \\
\text { the } \\
\text { scene }\end{array}$ & PM, I. \\
\hline $\begin{array}{c}\text { 24: Djhutymes } \\
\text { offers to his parents } \\
\text { [Amun]Hotep and } \\
\text { his wife(Fig. }\end{array}$ & $\begin{array}{c}\text { TT } 295 \text { of } \\
\text { Dhutmosi called } \\
\text { Paroy }\end{array}$ & $\begin{array}{c}\text { Tuhmosis } \\
\text { IV - } \\
\text { Amenophis } \\
\text { III }\end{array}$ & El-khokha & $\begin{array}{c}\text { Hall, south } \\
\text { wall, east } \\
\text { part. }\end{array}$ & (4-II) \\
\hline $\begin{array}{c}\text { 25:Pairy offers to } \\
\text { his parents (Fig. }\end{array}$ & TT 139 of Pairi & $\begin{array}{c}\text { Amenophis } \\
\text { III }\end{array}$ & $\begin{array}{c}\text { Shekh Abd } \\
\text { el-Qurna }\end{array}$ & Hall & (3) P.253 \\
\hline $\begin{array}{c}\text { 26: Ramose offers } \\
\text { his parents and } \\
\text { brothers. }\end{array}$ & $\begin{array}{c}\text { TT } 55 \text { of Ramose } \\
\text { III }\end{array}$ & $\begin{array}{c}\text { Amenophis } \\
\text { Akhenaton }\end{array}$ & $\begin{array}{c}\text { Shekh Abd } \\
\text { el-Qurna }\end{array}$ & Hall & (4-I), \\
\hline $\begin{array}{c}\text { 27: Ramose offers } \\
\text { his parents, brothers } \\
\text { and relatives. }\end{array}$ & $\begin{array}{c}\text { TT } 55 \text { of Ramose } \\
\text { III }\end{array}$ & $\begin{array}{c}\text { Amenophis } \\
\text { Akhenaton }\end{array}$ & $\begin{array}{c}\text { Shekh Abd } \\
\text { el-Qurna }\end{array}$ & Hall & (4-II) \\
\hline $\begin{array}{c}\text { 28:) Nebamun and } \\
\text { Ipuki offer to their } \\
\text { parents in a }\end{array}$ & $\begin{array}{c}\text { TT } 181 \text { of } \\
\text { Nebamun and } \\
\text { Ipuky }\end{array}$ & $\begin{array}{c}\text { Amenophis } \\
\text { III }\end{array}$ & El-Khokha & Hall & (7) ,P.288 \\
\hline $\begin{array}{c}\text { 29: Nakhetmin } \\
\text { offers to his parents. }\end{array}$ & TT 291 & $\begin{array}{c}\text { End of } 18^{\text {th }} \\
\text { Dynasy }\end{array}$ & $\begin{array}{c}\text { Deir el- } \\
\text { Medina }\end{array}$ & Chapel & (4), P.374 \\
\hline
\end{tabular}

\subsubsection{Scenes from the 19th Dynasty}

Table (2) Scenes from the $19^{\text {th }}$ Dynasty

\begin{tabular}{|c|c|c|c|c|c|}
\hline Brief description & TT\&Owner & Date & Location & $\begin{array}{c}\text { Place of } \\
\text { the scene }\end{array}$ & PM, I. \\
\hline $\begin{array}{c}\text { 30: Nekhtamun and } \\
\text { family offer to } \\
\text { brother Nefehotep. }\end{array}$ & $\begin{array}{c}\text { TT 335 of } \\
\text { Nekhetamun }\end{array}$ & Ramesses II & $\begin{array}{c}\text { Deir el- } \\
\text { Medina }\end{array}$ & $\begin{array}{c}\text { Burial } \\
\text { chamber B. }\end{array}$ & $\begin{array}{c}\text { No.(16), } \\
\text { P.402 }\end{array}$ \\
\hline $\begin{array}{c}\text { 31: Nebuemsheset } \\
\text { the wife of (T.O) } \\
\text { offers to her Parents. }\end{array}$ & $\begin{array}{c}\text { TT 335 of } \\
\text { Nekhetamun }\end{array}$ & Ramesses II & $\begin{array}{c}\text { Deir el- } \\
\text { Medina }\end{array}$ & $\begin{array}{c}\text { Burial } \\
\text { chamber A }\end{array}$ & $\begin{array}{c}\text { No.(10), } \\
\text { P.402 }\end{array}$ \\
\hline $\begin{array}{c}\text { 33: ( Stela ) On the } \\
\text { middle register, Karo } \\
\text { offers to his parents } \\
\text { and relatives. }\end{array}$ & TT 330 of Karo & Ramesses II & $\begin{array}{c}\text { Deir el- } \\
\text { Medina }\end{array}$ & $\begin{array}{c}\text { Turin Mus. } \\
\text { cat.1636 }\end{array}$ & $\begin{array}{c}\text { finds } \\
\text { P.398 }\end{array}$ \\
\hline $\begin{array}{c}\text { 34: Karo offers to his } \\
\text { parents, brothers and } \\
\text { wife. }\end{array}$ & TT 330 of Karo & Ramesses II & $\begin{array}{c}\text { Deir el- } \\
\text { Medina }\end{array}$ & $\begin{array}{c}\text { Chapel- } \\
\text { north wall- } \\
\text { east half }\end{array}$ & $\begin{array}{c}\text { No.(2) } \\
\text { P.398 }\end{array}$ \\
\hline $\begin{array}{c}\text { 35: Khabekhnet and } \\
\text { his wife Sahte offers }\end{array}$ & $\begin{array}{c}\text { TT 2 of } \\
\text { Khabekhnet }\end{array}$ & Ramesses II & $\begin{array}{c}\text { Dra Abu el- } \\
\text { Naga }\end{array}$ & Hall & $\begin{array}{c}\text { No. (4), } \\
\text { P.6 }\end{array}$ \\
\hline
\end{tabular}




\begin{tabular}{|c|c|c|c|c|c|}
\hline Brief description & TT\&Owner & Date & Location & $\begin{array}{l}\text { Place of } \\
\text { the scene }\end{array}$ & PM, I. \\
\hline \multicolumn{6}{|l|}{ to parents. } \\
\hline $\begin{array}{l}\text { 36: Amenwahsu and } \\
\text { family offer to } \\
\text { parents. }\end{array}$ & $\begin{array}{c}\text { TT } 111 \text { of } \\
\text { Amenwahsu }\end{array}$ & Ramesses II & $\begin{array}{c}\text { Shekh Abd } \\
\text { el-Qurna }\end{array}$ & Hall & $\begin{array}{l}\text { No.(3) } \\
\text { p.230. }\end{array}$ \\
\hline $\begin{array}{c}\text { 37: Nebsumenu } \\
\text { offers to his brother } \\
\text { Hunufer and his wife. }\end{array}$ & $\begin{array}{l}\text { TT } 183 \text { of } \\
\text { Nebsumenu }\end{array}$ & Ramesses II & El-Khokha & Hall & $\begin{array}{l}\text { No. (14- } \\
\text { II), P.290 }\end{array}$ \\
\hline $\begin{array}{c}\text { 38: Dhutemhab } \\
\text { offers to his brother } \\
\text { Amenhotep and his } \\
\text { wife. }\end{array}$ & $\begin{array}{l}\text { TT } 194 \text { of } \\
\text { Dhutemhab }\end{array}$ & Ramesses II & El-Asasif & Hall & $\begin{array}{l}\text { No.(5- } \\
\text { II), P.300 }\end{array}$ \\
\hline $\begin{array}{c}\text { Scene: } 39 \text { (TT.194)-) } \\
\text { Dhutemhab offers to } \\
\text { his father. }\end{array}$ & $\begin{array}{l}\text { TT } 194 \text { of } \\
\text { Dhutemhab }\end{array}$ & Ramesses II & El-Asasif & Hall & $\begin{array}{l}\text { No.(5- } \\
\text { IV), } \\
\text { P.300 }\end{array}$ \\
\hline $\begin{array}{c}\text { 40: Thay presents } \\
\text { offerings offers to his } \\
\text { parents Khaemter and } \\
\text { Tamit. }\end{array}$ & TT 23 of Thay & $\begin{array}{l}\text { Ramesses } \\
\quad \text { II- } \\
\text { Merenptah }\end{array}$ & $\begin{array}{c}\text { Shekh Abd } \\
\text { el-Qurna }\end{array}$ & Passage & $\begin{array}{c}\text { No. (34) } \\
\text { P.40 }\end{array}$ \\
\hline $\begin{array}{l}\text { 41: Irynefer, wife and } \\
\text { a son censing and } \\
\text { offer to the parents } \\
\text { and brothers. }\end{array}$ & $\begin{array}{c}\text { TT } 290 \text { of } \\
\text { Irinufer }\end{array}$ & Ramesses II & $\begin{array}{l}\text { Deir el- } \\
\text { Medina }\end{array}$ & Chapel & $\begin{array}{l}\text { No.(2), } \\
\text { P. } 372\end{array}$ \\
\hline
\end{tabular}

\subsubsection{Scenes from the 20th and 21st Dynasties}

Table (3) Scenes from the $20^{\text {th }}$ and $21^{\text {st }}$ Dynasties

\begin{tabular}{|c|c|c|c|c|c|}
\hline Brief description & TT\&Owner & Date & Location & $\begin{array}{c}\text { Place of } \\
\text { the } \\
\text { scene }\end{array}$ & PM, I. \\
\hline $\begin{array}{c}\text { 42: Amenemopet is making } \\
\text { offerings to his parents(Fig. } \\
\text { 35). }\end{array}$ & $\begin{array}{c}\text { TT } 148 \text { of } \\
\text { Amenemopet }\end{array}$ & $\begin{array}{c}\text { Ramesses } \\
\text { III }\end{array}$ & $\begin{array}{c}\text { Dra Abu } \\
\text { el-Naga }\end{array}$ & Hall & $\begin{array}{c}\text { No.(2- } \\
\text { I), } \\
\text { P.259 }\end{array}$ \\
\hline $\begin{array}{c}\text { 43: Amenemopet offers to his } \\
\text { grandparents Amenhotep and } \\
\text { Henutmete (Fig. 36). }\end{array}$ & $\begin{array}{c}\text { TT } 148 \text { of } \\
\text { Amenemopet }\end{array}$ & $\begin{array}{c}\text { Ramesses } \\
\text { III }\end{array}$ & $\begin{array}{c}\text { Dra Abu } \\
\text { el-Naga }\end{array}$ & Hall & $\begin{array}{c}\text { No.(2- } \\
\text { II) } \\
\text { P.259 }\end{array}$ \\
\hline $\begin{array}{c}\text { 44: Pabasa offers to his } \\
\text { parents, Pedubaste and } \\
\text { Tasentenhor (Fig.37). }\end{array}$ & $\begin{array}{c}\text { TT } 279 \text { of } \\
\text { Pabasa }\end{array}$ & Psamtik I & El-Asasif & Court & $\begin{array}{c}\text { No(.8) } \\
\text { P.358. }\end{array}$ \\
\hline
\end{tabular}




\section{Samples of the study:}

\subsection{Doc. 1(PL.1): Scene from the tomb of Amenhotep TT $345^{4}$ :}

The tomb owner Amenhotep offers to his parents Sntydjhout and Taghred .

Tomb: TT 345.

Tomb Owner: Amenhotep: "w`b s3 nsw tpy $n$ ( $3-h p r-k 3$ $\left.-r^{\mathrm{e}}\right) "$

wab-priest, Eldest king,s son of Tuthmosis I. ${ }^{5}$

Father : Sntydjhout

Mother: Taghred.

Date: 18 th Dynasty, Tuthmosis I.

Location: Shekh Abd elQurna.

Place of the scene: Hall, notrth wall, east half.

PM: I scene No(6), 414.

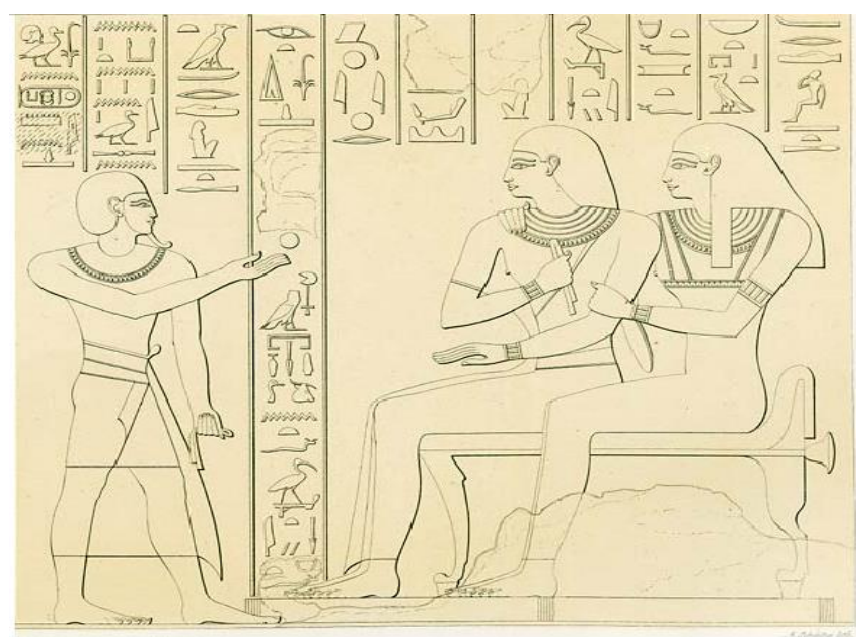

PL. 1: The Tomb owner Amenhotep consecrates offering to his parents Sntydjhout and Taghred ${ }^{6}$.

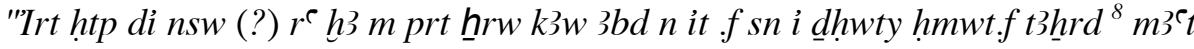

The

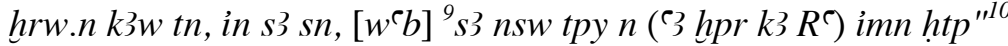

offering text reads $^{7}$ :

"making offering which the king gives (?)(Re?), a thousand of offerings to his father Sntydjhout (and) his mother Taghered true of voice, to your spirits, by your son, The wab-priest, royal son of (Tuthmosis I) Amenhotep.

The text of

the parents reads $^{11}$

\section{im3hy hr // t3 dsr snidhwty hmt.f mrt.f nbt pr t3hrd m3`t hrw ${ }^{12}$}

The honored one under? (in) sacred land (necropolis) Sntydjhout (and) his wife, his beloved, the mistress of the house Taghered true of voice.

\footnotetext{
${ }^{4}$ PM: I, No(6), 414.

${ }^{5} \mathrm{PM}, \mathrm{I}, 413$.

${ }^{6}$ After: Lepsius R., Denkmliler aus Aegypten und Aethiopien, III, No.9(f-right).

${ }^{7}$ Lepsius R., Denkmliler aus Aegypten und Aethiopien, III, No.9(f-right).

${ }^{8}$ Whale, (1987), 87.

${ }^{9}$ The missing part should be $\left(w^{c} b\right)$ "the purified priest", since the full title of Amenhotep is "w`b s3 nsw tpy $n$ ( 3 hpr-k3-r" According the title in: PM I, 413; Whale,(1989), 87.

${ }^{10}$ for the Transliteration of names and titles see: Whale, (1987), 87.

${ }^{11}$ Lepsius R., Denkmliler aus Aegypten und Aethiopien, III, No.9(f-right).

${ }^{12}$ for the Transliteration of names and titles see: Whale, (1987), 87.
} 


\subsection{Doc. 2(PL.2) : Scene From The Tomb of Amenemhat TT 82: The}

The tomb owner Amenemhet offers to his parents and ancestors in two rows of couples. ${ }^{13}$

Tomb: TT82.

Tomb owner: Amenemhet

"imn-m-ḩ̧ imy-r pr $n$ țity š̌ hlsbw it $n$ imn"14

Father: Dhutmose. ${ }^{15}$

Mother: Intef ${ }^{16}$ called Tawert. ${ }^{17}$

Date: $18^{\text {th }}$ Dynasty, Tuthmosis III.

Location: Shekh Abd el-Qurna.

PM,I, p.146 No.(4-I).

Publication: Davies N. G. and

Gardiner A. H. "The tomb of Amenemhet (No. 82), The Theban Tomb series, London, 1915.

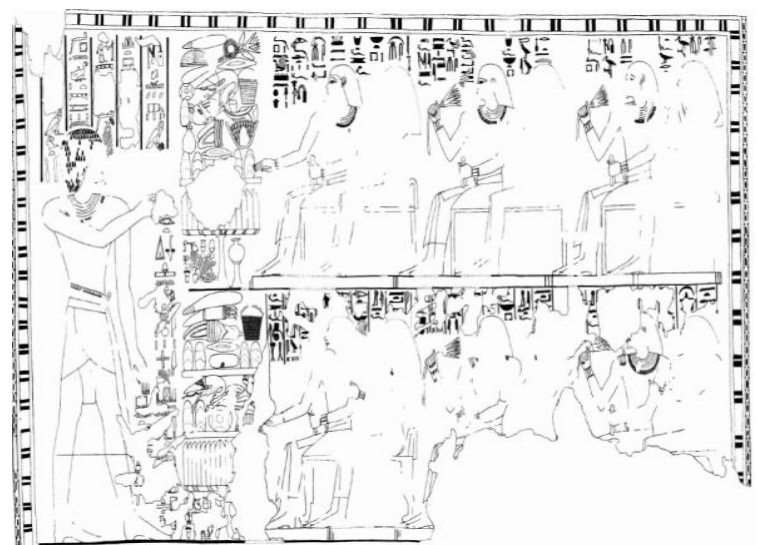

PL. 2: The Tomb Owner Amenemhet Offers to his Ancestors. $^{18}$

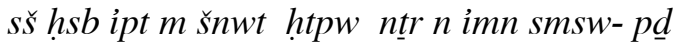

imy-r pr $n$ ț $3 t$ hry mrw n imn imn-m-ḩ3t

\section{The text of}

Amenemhat

" The scribe who reckons the grain in the granary of [divine offerings of $\operatorname{reads}^{19}$ : Amun], the master of ceremonies,' the overseer of ploughed fields, steward of the Vizier, chief of the weavers of [the house of (?) Amun], Amenemhat, the justified," 20

\section{The text of}

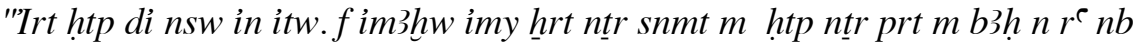

offerings "Making offerings which-the-King-gives to his fathers the revered ones who are reads $^{21}$ : in the Necropolis, feasting [them] with the ritual divine offerings come forth in presence every day". ${ }^{22}$

\footnotetext{
${ }^{13}$ PM,I, No.(4-I), p.146; Davies N. G. and Gardiner A. H. "The tomb of Amenemhet (No. 82), The Theban Tomb series, Tome 1, London, 1915, PL VII.

${ }^{14}$ Sethe, K. (1927-1930), Urkunden der 18, IV (second edition, revised). Leipzig, J. C. Hinrichs, p. 1043-64; Whale, 1989, 60 .

${ }^{15}$ Davies and Gardiner, (1915), 36.

${ }^{16}$ Whale, 1989, 61.

${ }^{17}$ Davies and Gardiner, (1915), 36.

${ }^{18}$ After: Davies and Gardiner (1915), PL VII.

${ }^{19}$ Sethe, 1927, p.1050 (c).

${ }^{20}$ The translation after : Davies and Gardiner, (1915), p. 34-35.

${ }^{21}$ This part of text is after Sethe, Urkunden $I V, 1054$, but without the end (n ra nb), this was added in Davies and Gardiner, ( 1915), 35,note(3).

${ }^{22}$ Davies and Gardiner, (1915), 35.
} 


\subsection{Doc.3: PL.3: Scene on stela from the tomb of Karo TT 330.} (Middle register)The Deceased Karo offers to his parents and relatives.

Tomb: TT. 330.

Tomb Owner: Karo, Servant in the Place of Truth.

Father: Simut $^{23}$.

Mother: Peshedu.

Date: 19th Dynasty, Ramses II.

Provenance: Deir el-Medina.

Location: Turin Mus., No.50012, cat.1636.

Measure: h. $76 \mathrm{~cm}$, w. $55 \mathrm{~cm}$.

PM, I, finds, p.398.

Publication of the Tomb: Bruyère, $B$. IFAO, (1925), Rapport sur les fouilles de Deir el Médineh (1923-1924), Cairo, pp. 93-95.

50012, cat.1636.

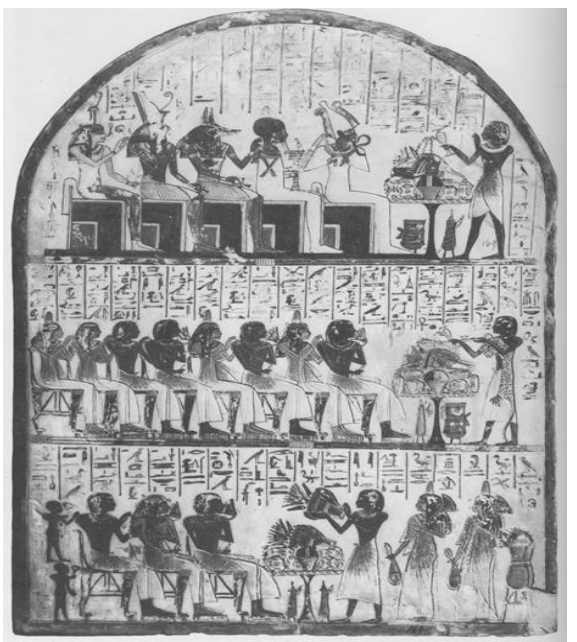

PL.3: Stela of Karo in Turin Mus., No.50012, cat.1636. On the middle register, the tomb owner Karo offers to his parents and relatives ${ }^{24}$
The text of offerings $\operatorname{reads}^{25}$ :

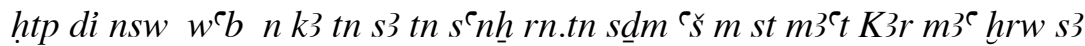

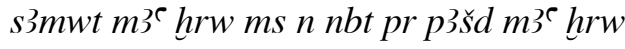
make the offering, pure, pure, to your ka by the hands of your $\operatorname{son}^{26}$ who makes your name a live, the servant in the place of truth, karo, justified. The son of Simut, justified, was born by the lady of the house Pashed, justified. ${ }^{27}$

\footnotetext{
${ }^{23}$ Rossi, F., Fabretti, A., (1882), Regio Museo Di Torino, Volume I , Museo Egizio Di Torino, Turin, p.179.

${ }^{24}$ After: Tosi, M. and Roccati, A. (1972), Stele e altre epigrafi di Deir el-Medina n. 50001 - n. 50262, Turin, Museo Egizio di Torino. 266.

${ }^{25}$ Tosi \& Roccati.(1972), 48.

${ }^{26}$ In spite of the presence of the brothers, the deceased used the word (your son) towards all the guest, perhaps because the priority in presenting was the offering to the parents.

${ }^{27}$ Tosi \& Roccati.(1972), p.48.
} 


\subsection{Doc.4(PL.4) a scene on plaster from the tomb of Karo TT330. The Deceased Karo offers to his parents and sister. ${ }^{28}$}

Tomb: TT. 330.

Tomb Owner: Karo, Servant in the Place of Truth.

Father: Simut ${ }^{29}$.

Mother: Peshedu.

Date: 19th Dynasty, Ramses II.

Provenance: Deir el-Medina.

Location: Deir el-Medina, TT 330.

PM, I, No(2), p.398.

Place of the scene: Chapel, north wall, eastern half.

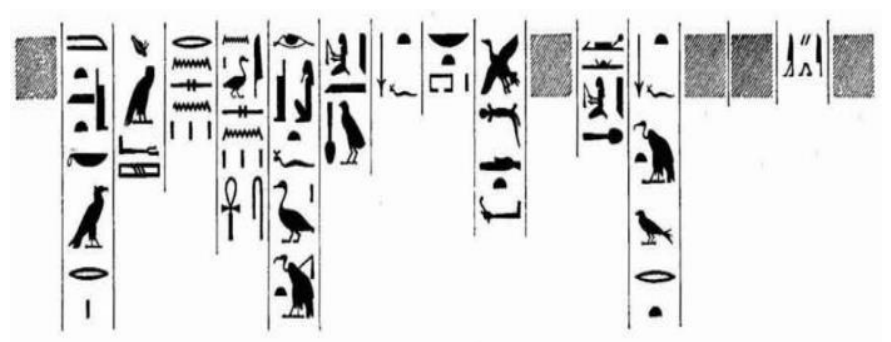

PL.4: The published text of the scene of Karo while offering to his parents and relatives. ${ }^{30}$

\begin{tabular}{|c|c|}
\hline $\begin{array}{l}\text { The Text of } \\
\text { parents reads }^{31} \text { : }\end{array}$ & 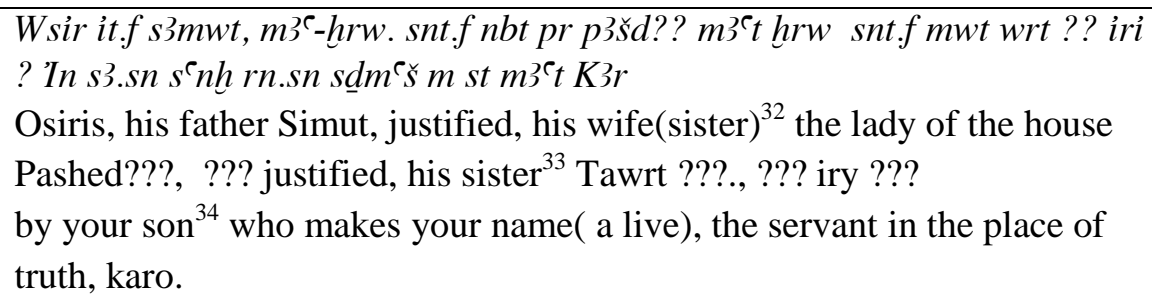 \\
\hline
\end{tabular}

\footnotetext{
${ }^{28}$ No figure is available for this Doc.4, Bruyère, only described the scene and the hieroglyphic text in his publication: Bruyère, B. IFAO, (1925), Rapport sur les fouilles de Deir el Médineh (1923-1924), Cairo, 93-95; According Bruyère, the deceased Karo is standing and offerings to eight people seated one behind the other. 29 - Rossi, Fabretti, p.179.

${ }^{30}$ Bruyère, IFAO, (1925), 93-95.

${ }^{31}$ Bruyère, B. IFAO, (1925), Rapport sur les fouilles de Deir el Médineh (1923-1924), Cairo, 93-95.

${ }^{32}$ Sometimes ancient Egyptian used the ward snt for wife and sister.

${ }^{33}$ Because of the poor state of the text, Bruyère( 1925), 94, replaced the on name of $(t 3 w r t)$ with this can be understood easily in the stela 50012 in the Turin Museum where the sister's name appears clear.

${ }^{34}$ In spite of the presence of the sister, the deceased used the word (your son) towards all the guest, perhaps because the priority in presenting the offering is for the parents.
} 


\subsection{Doc. 5 PL.5: Scene from the tomb of Thay TT ${ }^{23}$. The Tomb owner Thay offers to his parents and relatives ${ }^{35}$.}

Tomb: TT.23.

Tomb Owner: Thay.

Father: Khaemter

Mother: Tamit

Date: $\quad 19^{\text {th }} \quad$ Dynasty,

Merenptah.

Location: Sheikh abd elQurna. $^{36}$

Place of the scene: Passage. PM scene no. (34), P.40.

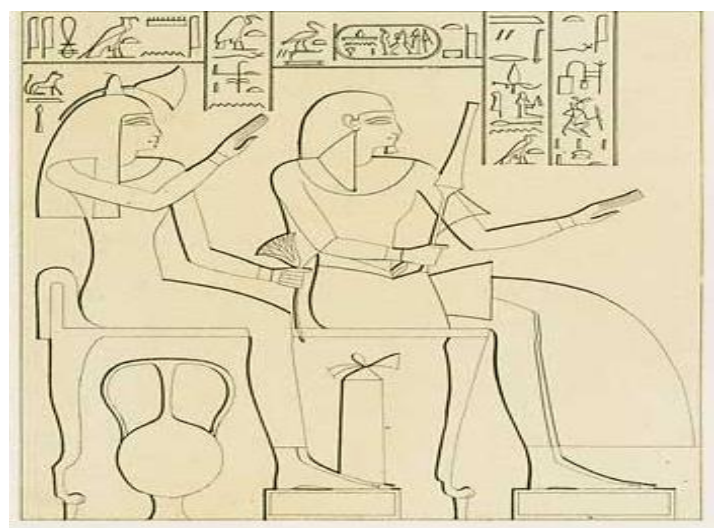

PL.5: The Tomb owner Thay offers to his parents and relatives $^{37}$

The Text of the parents reads ${ }^{38}$ :

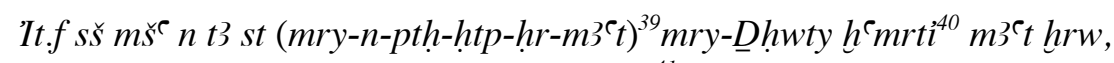
mwt ff šm $y$ t $n$ imn $t 3 m i^{41} m 3^{`} t$ hrw.

His father the scribe of soldiers of the palace of (Merenptah) beloved of Djhuty, Khamteri true of voice, his mother chantress of Amun,

Tami, justified
The Text of

Thay reads: ${ }^{42}$

\section{s3.f s'nh rn.f, sš nswt s't $n n b-t 3 w y, t 3 y$.}

His son (who) revive his name, the royal scribe of correspondence of the Lord of the Two Lands ${ }^{43}$ Thay.

${ }^{35}$ PM, I, 40, No.34.

${ }^{36}$ Kampp-Seyfried F., “Thebes, Sheikh Abd el Qurna.” In Bard K. (ed.) Encyclopedia of the Archaeology of Ancient Egypt, London, 1999), 1006-1008.

${ }^{37}$ After: Lepsius, C. R., Denkmäler aus Aegypten und Aethiopien, III P.199(g).

${ }^{38}$ L.D, III, No, 199 (g).

${ }^{39}$ Sjef Willockx, The cartouche names of the New Kingdom, 2008, 37.

${ }^{40} \mathrm{PM}, \mathrm{I}, 38$.

${ }^{41}$ PM, I, 38.

${ }^{42}$ Text from the source: L.D, Text, III, 253.

${ }^{43}$ Thay was promoted to the position of the 'royal scribe of correspondence of the Lord of the Two Lands', that is a personal secretary of the king. See: G.A. Belova and S. V. Ivanov (eds.),

Tomb of Thay (TT23): Seasons 2006-2008, Achievements and problems of modern Egyptology, Proceedings of the International Conference ,Moscow 2012157. 


\subsection{Doc. 6 PL.6: Scene from the tomb of Khabekhnet TT2.3.6 Khabekhnet and his wife Sahuty offering to the parents of Khabekhnet $^{44}$.}

Tomb: TT.2

Tomb Owner: Khabekhnet.

Date: 19th dynasty, Ramesses II.

Wife : Sahuty.

Father: Sennedjem.

Location: Deir el-Medina.

Place of the scene: The right thickness between the hall and the chamber.

PM,I, scene no. (4).

Publication:1- Bruyère, B. , MIFAO 86 (1952), Tombes Thébaines de Deir el Médineh à décoration monochrome, $\mathrm{p}$. 22-57, PL I-XII,

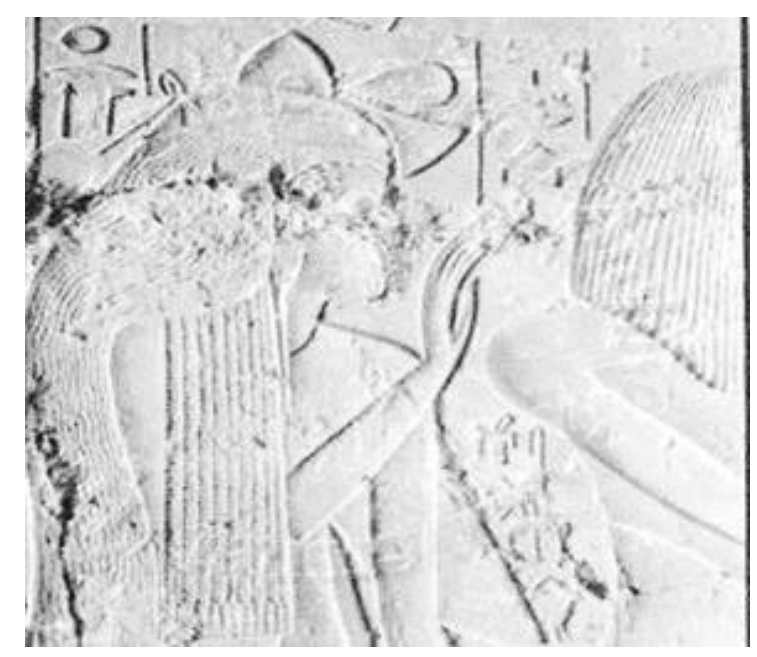

PL. 6: The right part of the scene on which Khabekhnet and his wife Sahuty offering to the parents of Khabekhnet. ${ }^{45}$

The text of

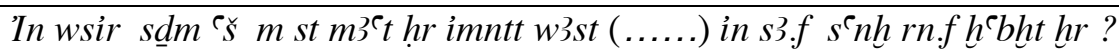
Sennedjem To Osiris, Servant in the Place of Truth to the west of Thebes(......) by reads $^{46}$ : his son (who)make his name a live Khabekhnet.(........)

\footnotetext{
${ }^{44}$ PM, I, p.6;

${ }^{45}$ After Scott photos in: (https://www.schott.uni-trier.de/schott.php); This part of scene and rest parts are not available in the Publication of Bruyère (1952), nor that of Černy, (1949).

${ }^{46}$ Černý, (1949),P.10.
} 


\subsection{Tomb Owner's Offerings as piety Towards Parents}

A number of 44 scenes represented the tomb owner offers to his relatives, 25 of which show the deceased offering to his parents and the other 19 scenes show him offerings to other relatives. The offering scenes to the parents are more than scenes for others $^{47}$. These scenes of parents while receiving offering from their son, are only a collection of a greater number of scenes that represented the parents inside the tombs of their sons in a position of honor and respect. In an earlier study of Whale (Whale, 1989) it was proved that both parents of the tomb owner were represented in fifty-two tombs.

Certainly, this number of offering scenes to the parents by the tomb owner or others, due to the high filial piety during the New Kingdom period carries important meaning and goals. The parents of the tomb owner were the most important element of the extended family, therefore, talking care of them in old age and after death was more than others (Whale, 1989)

In PL.1, PL.5, PL.6, when the Tomb owner offers to his parents, as in most of the scenes under study, this could be included within the general frame of piety towards the parents which related to the role of the son and his responsibility for the funeral cult of his parents, whether it was a condition of inheritance or just moral motive as result of religious and social teachings. Through the table of scenes attached to the introduction, that analysis can be also applied to the scenes 1( TT.15), 9(TT.18), 14(TT.122), 19(TT.45), 20(TT.17), 21(TT.162), 24(TT.295), 28(TT.181), 29(TT.291), 31(TT.335), 36(TT.111), 39(TT.194), 42(TT.184), 44(TT.297). These scenes can be distinguished by the traditional appearance of the parent as seated couple while receiving offerings from their son, the owner of the tomb, whether he is alone with his wife. This is the same traditional appearance of the tomb owner and his wife when they receive the offerings of their children or others.

One of the important element of the mortuary cult of the parents is the offering rituals on the feasts and occasions which the ancient Egyptians believed were useful to the dead (Hartwig , 2004). Offering to the parents translated the desire of the tomb owner to cause his parent's name to live by maintains their tomb and presenting the necessary sacrifice. This religious piety towards the parent connected with the role of the son as Horus towards his parents after death.

One of the important element of the mortuary cult of the parents is the offering rituals on the feasts and occasions which the ancient Egyptians believed were useful to the dead (Hartwig , 2004). Offering to the parents translated the desire of the tomb owner to cause his parent's name to live by maintains their tomb and presenting the necessary sacrifice. This religious piety towards the parent connected with the role of the son as Horus towards his parents after death.

\subsection{Tomb Owner's Offerings as cult of ancestors.}

In some other cases, the tomb owner offers to his parents with other persons as the case of PL. 2, PL.3, PL.4. These scenes can be classified to another classifications but it also bore the meanings of piety, whether towards the parents or towards others participating in the offerings. When the tomb owner offers to the parents among other

${ }^{47}$ This classification of the scenes to the parents is after the list in PM, 480. 
relatives of brothers or ancestors, this connected to the ancestor cult (Davies \& Gardiner , 1915) that developed in the New Kingdom and appeared strongly in Deir El-Madina. ${ }^{48}$ This kind of cult was more active in homes by keeping ancestor busts or for blessing and protection. The stela on PL.3 is a good example for many others which were made by the living for their ancestor's cult and were kept sometimes inside the tomb ${ }^{49}$.

Ancestor's cult appeared in the walls of the tombs through the scenes of offerings to the ancestors as the case PL2, PL4, and the scenes on the list no. $4\left(\right.$ TT.27) ${ }^{50,} 10\left(\right.$ TT112) ${ }^{51}, 23(\text { TT295) })^{52}, 43(148)^{53} 34$ (330). ${ }^{54}$ or keeping the mentioned stelae inside the tomb as the case of scenes, PL.3 The ancestors cult was established for the dead who still in memory, when the spirits of the dead ancestor were satisfied with offerings, they were benign. But when they were dissatisfied for any reason, they were able to create all kinds of chaos on Earth. Their dissatisfaction can manifest itself in a painful form, a sinister harbinger or a disease. In some cases, the cause of unexpected evil was, according to the sources, "the death of any man or woman." Other texts refer to the "eye of the dead" which can cause misfortune.(Teeter , 2011)

Another Kind of ancestor's cult scenes under the topic of the study is the cult of Ax iqr in $\operatorname{Re}$ (on the scenes list no.30) the excellent / able spirit of Re. This scene is considered rare on the walls of tomb as it appeared only on TT 250 and TT 335, but it was repeated often on the stone stelae. (Bruyère , 1926) A category of transfigured spirits that was thought to have a special relationship to and communication with the gods, especially Re. The scene on the tomb wall 30 from TT $335^{55}$ is the best example of this cult. The tomb owner Nekhtamun and his family offer to his brother Nefehotep the Ax iqr in Re. (Bruyère , 1926) Nekhetamun presented himself to Neferhotep in the text as "your brother "sn.k", In his study of this scene, Bruyere thinks that they are real brothers (Bruyère , 1926). According to Demarée they were not real brothers and "sn" 'Brother' on the text means 'colleague', as often in texts from Deir el-Medina (Demarée , 1983).

Most of the Ax iqr in Re stelae were kept in the houses or the village shrines in Deir el Medina. The majority of them are modest round-topped stone monuments that show the akh seated, usually before a table of offerings. This branch of the ancestor cult was established for some character that was believed to rise a higher degree among the dead as a result of the god's approval. Those persons were worshiped after death for certain reasons, the most important of which is the perpetuation of their memory, pride in the family, and earning their protection for the living. The Ax iqr in Re stelae can be distinguished by the individual seated appearance and the title itself (Demarée , 1983).

\footnotetext{
${ }^{48}$ Ann H. Bomann, The Private Chapel in Ancient Egypt: A Study of the Chapels in the Workmen's Village at El Amarna with Special Reference to Deir El Medina and Other Sites, Kegan Paul International, 1991, p.68.

${ }^{49}$ PM, I, finds,P.398.

${ }^{50}$ PM, I, (16) P.243.

${ }^{51}$ PM, I, (5), P.230.

${ }^{52}$ PM, I, (4-I), P.377.

${ }^{53}$ PM, I, (2-II), P.259.

${ }^{54}$ PM, I, (2) P.398.

${ }^{55}$ PM, I, (16), P.402
} 


\subsection{Tomb Owner's Offerings as appreciation for the Royal tutor and Royal nurses.}

A third type of tomb owner's offerings scenes can be classified as thanksgiving for some favors. This classification occurred when the tomb owner offers to one of his parents or to his wife when they have one of two titles "royal tutor" or "royal nurse". On the scene 22(TT.64), ${ }^{56}$ the tomb owner Hekerneheh offers to his father the royal tutor Hekreshu alone without his wife (the tomb owner's mother) (Newberry , 1928). The scene on the list No. 18 from TT.93 showed kenamun offering to his mother Amenemhab, the royal nurse, also she is represented alone without her husband. (Hershey , 1990).These cases of scenes represented the tomb owner's pride of kinship relation to the royal family as he became a foster brother of the royal princes grace of his father or mother. These offerings could be seen as gratitude and appreciation from the tomb owner to his father or his mother who were the reason for his distinctive status as a foster brother of the royal princes, this status which certainly brought him many advantages in society.

On scenes 11, 12, 13 (TT.85), ${ }^{57}$ Amenemhab (called Mahu)offers to his wife Baki carrying Amenophis II. These Three scenes could be classified to the same previous category. On the three scenes Amenemhab offers to his wife Baki while suckling or carrying a royal prince. Baki who held the title "royal nurse" also was offered alone in TT.85, she was represented in a larger size than her husband and even larger than the traditional size of women (Roehrig, 1990). The privileged position of the royal nurse Baki supported her husband to become commander of the army, as is the case for some other nursing husbands (Virey , 1891). It seems that the offering scenes at the tomb TT.85 express gratitude and appreciation of Amenemhab for his wife, who was the reason for the distinguished position he obtained.

\subsection{The Living Tomb Owner Offers To The dead Relatives:}

Through the study of the scenes which represents the owners of the tombs offer to relatives or generally other persons, and because of the absence of death signs in most the texts of tomb owners, we can reach an important analysis that the owner of the tomb in these scenes is a live in the realm of the living, not the dead.

The text of PL.2 "Making offerings which-the-King-gives to his fathers the revered ones who are in the Necropolis, feasting [them] with the ritual divine offerings for ancestors every day"(Davies \& Gardiner , 1915). The owner of the tomb Amenemhat refers to his parents and ancestors by the word "fathers" after the offering formula, the reference to the death of the receiver concluded in the phrase "who are in the necropolis"(Davies \& Gardiner , 1915) in clear evidence that they are in the world of the dead and he is in the world of the living.

The second evidence which confirms that the tomb owner is alive when he offers to relatives that in all the scenes in which the tomb owner, is receiving offerings from others, he is facing the door of the tomb from which the visitors are supposed to enter. At the same time, his visitors turn their backs to the entrance because they are alive. But in the case 1 (PL.1) and the case 2 (PL.2), when the tomb owner presents offerings to parents(PL.1), his ancestors ( PL.2),to the vizier, ${ }^{58}$ and to the workers

\footnotetext{
${ }^{56}$ PM, I, (7) P.128

${ }^{57} \mathrm{PM},(16), \mathrm{p} .172,(\mathrm{~B}, \mathrm{C}), \mathrm{p} .173$.

${ }^{58}$ For the scene of The Tomb owner Amenemhet offering the vizier Iahmes and his wife see:
} 
(Davies \& Gardiner , 1915), in these cases he himself turns his back to the entrance. Symbolically, this means that he is alive and the receiver of offerings belongs to the kingdom of the dead (Davies \& Gardiner , 1915).

One of the important proof that the tomb owner presents himself alive when offers to relatives or generally other persons, that the receiver of offerings is called Osiris, or held the adjective "revered" "Im3hy" which indicates his death, while the tomb owner did not identified as Osiris when he offers, this occurred also in some other tombs ${ }^{59}$. When the owner of the tomb wears the costume of the sim-priest and performs the funeral rites to the deads he plays the role of the living Horus who performed the funeral rites before the dead Osiris (Shahawy, 2005). Whether his actual occupation was a priest on not, the living son serves as the main funerary priest of his parents, he is the responsible to sustain their funerary cult and provide the required offerings (Dean , 2015).

\subsection{Tomb Owner Offers to Relative to Revive Their Names:}

Reviving the name of the dead was an important aim from the offering presented by the owner of the tomb to his parents or ancestors. The verb $s^{\top} n h$ which means to make live; to perpetuate ${ }^{60}$, is often used in the texts of offerings to the relatives from the same family.

In Doc.5: from the tomb of the royal scribe Thay TT.23, The Tomb owner,

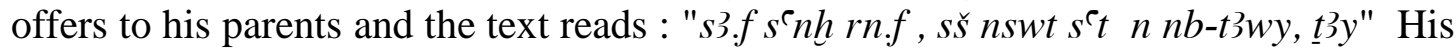
son (who) revive his name, the royal scribe of correspondence of the Lord of the Two Lands Thay.

In Doc.6:, the scene from the Tomb TT.2, represented Khabekhnet and his wife Sahuty while offering to Sennedjem and Eineferty, the parents of Khabekhnet.

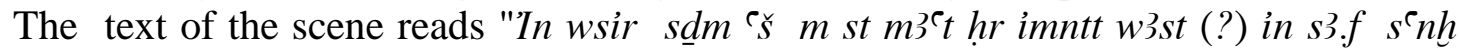
$r n . f$ hrbht hrr (?)" To Osiris, Servant in the Place of Truth to the west of Thebes(?) by his son who make his name a live Khabekhnet(?)

The stela Doc. 3, in Turin Mus., No.50012 (Del Vesco \& Poole , 2014), from the tomb of Karo TT. 330. The scene shows the tomb owner is offering to his parents and relatives. The text of offerings reads: "make the offering, pure, pure, to your ka by the hands of your son ${ }^{61}$ who makes your name a live,...." (Tosi \& Roccati , 1972).

In Doc. 4, the scene on plaster from the tomb of Karo TT.330, shows the tomb owner is offering to his parents and relatives. The text reads: "in s3.sn s $s^{\top} h$ rn.sn $s \underline{d} m-\Upsilon \check{s} m s t m 3^{\complement} t K 3 r$ " by your son who makes your name a live, the servant in the place of truth, karo.

In the scene of on the tomb TT. 45, Davies supposed That Djehutyemheb (the second owner of $19^{\text {th }}$ Dynasty) reused the scene of Djhwty (the first owner of $18^{\text {th }}$ Dynasty), and added some modifications. Djehutyemheb visibly wanted to make an

PM: I, No(3), 164; Davies and Gardiner, ( 1915), 32.

${ }^{59}$ The honored persons who received the offerings from the tomb owners in such scenes, were identified as osiris while the owner himself did not held this identification in the same scenes. for example of these scenes was in TT.45, TT. 330, TT.181, TT. 291, TT. 335, TT. 2, and TT. 148.

${ }^{60}$ Wb. 4, 46.4-47.13.

${ }^{61}$ In spite of the presence of the brothers, Karo used the word of (your son) towards all the receivers, perhaps because the priority in presenting the offering to the parents. 
act of piety towards his own parents by presenting the offerings to revive their names (Davies \& Gardiner, 1915), The red text of the offering shows that the offerings were presented" by his son who revive his name, "in s3.f snh rn.f "

Through these previously mentioned documents, it seems that the phrase that mentioned, in various forms, the revival of the dead's name, was addressed in particular to the parents more than other relatives. The tomb owner wants to revive the name of the parents in the wall of the tomb and other monuments.

\subsection{Tomb owner as sem-priest and similarity with iwn $m w t$. $f$ :}

In a group of scenes the owner of the Tomb appears as sem priest wearing the leopard skin while offering to his parents or other relatives. This occurred in the some scenes in tombs TT.82 and TT.148 twice, TT. 330, TT.112, TT. 181, TT. 335 and TT.27. Many of those figures that represent the son as a priest performing funeral cult for his parents were removed by the followers of Akhenaten, and sometimes the figures of the seated parents were also influenced by this religious revolution (Dean , 2015). The repetition of the sem- priest dress in those scenes gives a specific meaning related to the role of Horus as the protector of his father's position. The appearance of the son in his cultic role for protecting and inheriting his father's position while offering to him is very similar to the role of $i w n m w t$. $f$, who symbolized the eldest son of the royal family and who cared for the deceased king (Wilkinson , 1992). These scenes of iwn mwt.f was repeatedly represented on the walls of the royal and divine monuments during the new kingdom. Iwn mwt.f also appears as a priest wearing a leopard skin and interpreted as royal $k 3$ descended from one generation to the next and from father to son. The role of iwn mut.f was performed by some priests on behalf of the son responsible for the cult of the royal $k 3$ symbolizing the eldest son and successor of the king (Bell , 1985) Steven R. W. Gregory argued that iwn mwt.f does not represent the actual son of the dead king, but rather an embodiment of an idea that represents the renewed, transitional and always youthful aspect of the of the gods who maintain the cosmic order, not only Osiris or his heir Horus, but, in Thebes, all the progeny of Amun Ra, which is represented in the transmission of the $K 3$ from father to son (Steven, 2015). At the level of the private ideology, as in the case of the class of tomb owners under the study, when the son stands in front of his son, he is considered to be the $k 3$ that was transferred from his father (Karol ,2010), and at this moment he tries to restore the youth and the position to his father in the other world (Hartwig , 2004). The $k 3$ of the individual was the $k 3$ of his ancestors, it is the life that was passed on through the ensuing generations. Some argue that the $k 3$ is a genetic memory of the deceased and not an aspect of individual (Padgham , 2012). which is almost the same idea of iwn mwt.f. This similarity in role and appearance between the son while offering to his parents in sem-priest dress and the role of iwn mwt.f needs further study for more understanding.

\subsection{The "Eldest son" who revive the name of the dead:}

The tomb owners are supposed to receive the mortuary offerings cult from their relatives, but in scenes of their tombs (PLs 1, 2, 3, 4, 5, 6) they performed their normal role on the mortuary cult for their parents. The scenes in this case can be added to the scenes which represent the owner while performing his daily roles and activities, one of the important roles during his life to offers to the $K 3$ of his parents. Ideally, the son, as Horus, who held the title "Eldest son" was the one who is responsible of the mortuary cult for his parents, perhaps motivated by the fact that 
inheritance was contingent on his performance of these activities (Hartwig, 2004) . The "Eldest son" of the deceased was one of the most important characters in the funeral pageant. His presence was very important as what confirmed that the deceased was an Osiris and his beloved son was Horus. It also guaranteed the son's future role, who by observing the funerary rites for the deceased in turn assured his inheritance (Shahawy, 2005) .

The importance of having an heir or "Eldest son" to oversee the mortuary cult after death appears in Padi-Sobek's lament for himself in which he expresses his sadness that he does not have a son to help him survive after death and therefore he will be forgotten and not exist after death (Heragi , 2017). During the New Kingdom, the son who was designated for this role and held the title "eldest son.". In cases where there were no sons, a brother, a daughter, or even the widowed wife would assume the role and title of "eldest son" (Teeter, 2011).

Besides the eldest son, priests from the local temple or special mortuary priests (hmw-k3 ) could be entrusted with the funeral, the burial, and the long-term continuation of the deceased's mortuary cult (Hartwig , 2004). This role of the eldest son was shortened and expressed on funerary monuments, especially the stelae, with the expression "who revives his name " or "who perpetuates his name". The conclusion that Nelson Hurset reached in his study (Nelson-Hurst , 2010) of the 174 known examples of the "s $s h r n . f$ " formula "who revive his name", is that this role was originally granted to the eldest son since the Old Kingdom. Due to some political circumstances, the brother participated the son in this role and held this title during the first intermediate period. The brother excelled in obtaining this role specifically during the Thirteen Dynasty. The matter returned again as it was, and the responsibility of reviving the name of the parents became the duty of the son in the second intermediate period (Nelson-Hurst , 2010) and during the period of the New Kingdom (Teeter , 2010).

\section{Conclusion:}

Group of scenes represented the owner of the tomb practicing rituals and offering to his parents and other relatives in his own tomb. With a careful study of these scenes, and the accompanying texts, it becomes clear that the owner of the tomb is in the world of the living, not the dead.

For the tomb owner's offering to his parent, one can understand that the tomb owners want to express their love for their parents by representing them in the wall of the tomb, as the parents probably depicted the children in theirs. The parents were responsible for their children at their childhood and the children were responsible for parents in old age and for the mortuary cult after death (Lacovara , 2016). These scenes are part of many others which reflected piety of the sons towards the parents. These scenes are similar in purpose to the scenes that represent the owner of the tomb himself while receiving the offerings from his son. The offerings scenes of the tomb resulted from the rise of piety towards the parents in the new kingdom.

When the tomb owner offers to the parents among other relatives of brothers or ancestors, this connected to the ancestor cult (Davies \& Gardiner , 1915) that developed in the New Kingdom especially on the community of Deir El-Medina. The cult of ancestors produced a large number of monuments such as busts, stone stelae, and scenes on the walls of tombs. Offering to the ancestor is considered to be one of the communication ways between the living and the dead, such as "Letters to the 
dead" and the "Apples to the living". The living invented these ways to communicate with the dead for several reasons, the most important of which to supply food for the $k 3 w$ of ancestors, commemoration of their memories in the living community, revive their names and to guarantee the protection of dead or even the prevention their evil.

In two cases of the study, the tomb owner offered to one of his parents who held the titles "Royal Tutor" for father (scene 22,TT.164) and "Royal Nurse" for mother (scene 18 ,TT.93). These offering scenes represented the tomb owner's pride of kinship relation to the royal family as he became a foster brother of the royal princes by his father or his mother. The title of the "Royal Tutor" of the tomb owner's father in the first case supported the tomb owner to obtain the same title. These offerings scenes could be seen as gratitude and appreciation from the tomb owner to his father or his mother who were the reason of this relation.

Only on the tomb TT.85, in three scenes, the tomb owner offered to his wife who held the title "Royal nurse" It seems that the wife supported her husband to have the distinguished position as leader of the army. The tomb owner presented the offering to his wife in large size to express appreciation for her favors.

Ideally the son of the dead who held the title "Eldest son" was responsible for reviving the name of his parents after death. In some cases the brother or other relative of kinship held this title. This responsibility is expressed in the texts of the tomb by the expression "s $s^{\top} h r n . f / k$ " "revive his/your name".

The physical meaning of the son's role which translate the term "revive the name" of his parents were represented in some actions such as completing or constructing the tomb if necessary, conducting the funeral and administering the mortuary cult especially the offerings for the kA in feasts (Baines , 2002). The performing of these practices for the dead parents was a condition of obtaining their inheritance in addition to other worldly tasks such as caring for the family and young siblings.

\section{Bibliography:}

-Ann H. Bomann, The Private Chapel in Ancient Egypt: A Study of the Chapels in the Workmen's Village at El Amarna with Special Reference to Deir El Medina and Other Sites, Kegan Paul International, 1991.

-Assmann , J. (2005), Death and Salvation in Ancient Egypt , translated from German by David Lorton, Ithaca, New York : Cornell University Press .

-Baine,. J., Burial and the dead in ancient Egyptian society, Oxford, 2002,

-Bell, L. 1985. Luxor Temple and the cult of the royal ka. Journal of Near Eastern Studies 44: 251-94

-Bleeker, C. J.,(1963 ) Sacred Bridge: Researches into the Nature and Structure of Religion, VII, Leiden: Brill.

- Bruyère,M. Bernard (1926), Rapport sur les fouilles de deir el médineh, (19241925).

-Carnarvon, and H. Carter.(1912). Five Years' Explorations at Thebes: A Record of Work Done 1907-1911. Oxford: Oxford University Press.

-Davies N. G. and Gardiner A. H. (1915), The tomb of Amenemhet (No. 82), The Theban Tomb series, Tome 1, London . 
- Demarée, R.J., (1983), The Ah iqr n Ra -Stelae On Ancestor Worship in Ancient Egypt, Leiden.

-Faulkner, R. O. (1973), The ancient Egyptian Coffin Texts (Spells 1-354). Warminster: Aris \&

Phillips.

------- (1969) The Ancient Egyptian Pyramid Texts,Utterance 371, Oxford: Clarendon Press.

-Hartwig, M. (2004), Tomb painting and identity in ancient Thebes, 1419--1372 BCE. Turnhout, Fondation Égyptologique Reine Élisabeth; Brepo

-Heragi, M. (2017) self-lamentation in ancient Egyptian autobiographies during ptelomaic period, unpublished PH.D dissertation: Minia University.

-Lacovara, P. (2016) The World of Ancient Egypt: A Daily Life Encyclopedia [2 volumes], New york :Library of Congress.

- Margaret Dean, (2015), Damnatio Memoriae in Non-Royal tombs: case Studies in the Theban Necropolis. Theses, Geogia State University.

-Mark Vygus, (2012), Hieroglyphic Dictionary , Electronic version in: (https://www.pyramidtextsonline.com/MarkVygusDictionary.pdf)

-Mysliwiec, K. (2010) "Father and eldest son's overlapping feet", CASAE 40, Studies in honor of Edward Brovarski, p. 305-334, Le Caire.

-Nelson-Hurst, M. G. (2010) " who causes his name to live' the vivification formula through the Second Intermediate Period" CASAE 39: University of Pennsylvania.

Ockinga, B. (2009) The Tomb of Amenemope (TT 148). Vol. 1: Architecture, Texts and Decoration, Australian Centre for Egyptology Reports 27, Oxford .

-Porter, B. and Moss, R. L. B. (1960), Topographical bibliography of ancient Egyptian hieroglyphic texts, reliefs, and paintings I: The Theban necropolis Part 1, Private tombs (second edition).Oxford: Clarendon Press.

- Roehrig, Catharine Hershey, The eighteenth Dynasty titles royal nurse (mn't nswt), royal tutor (mn' nswt), and foster brother/sister of the Lord of the Two Lands (sn/snt mn' n nb tSwy), Ph.D.University of California, Berkeley, 1990

- Rossi, F., Fabretti, A., (1882), Regio Museo Di Torino, Volume I, Museo Egizio Di Torino, Turin.

-Sethe, K. (1927), Urkunden der 18, IV (second edition, revised), Leipzig, J. C. Hinrichs.

-Shahawy, A. (2005), The Funerary Art of Ancient Egypt, Cairo: American University Press.

- Shang-Ying Shih, Death in Deir El-Medina: A Psychological Perspective, University of California, Berkeley, 1997.

- Steven R. W. Gregory, The role of the Iwn-mwt.f in the New Kingdom monuments of Thebes, British Museum Studies in Ancient Egypt and Sudan 20 (2013): 2546.

-Teeter, E. (2011), Religion and ritual in ancient Egypt, New york :Library of Congress.

-Taylor, John H. (2001), Death and the Afterlife in Ancient Egypt. Chicago: University of Chicago Press.

- Tosi, M. and Roccati, A. (1972), Stele e altre epigrafi di Deir el-Medina n. 50001 n. 50262.

Turin, Museo Egizio di Torino.

- Virey, PH.,(1891), Sept Tombeaux Thébains de la XVIIIem Dynastie, Publies par les membres de la mission archeologique Française au Caire sous la direction de m. Urbain Bouriant, Cairo 
-Whale, S. (1989), The Family in the Eighteenth Dynasty of Egypt: A study of the representation of the family in the private tombs. Sydney : Australian Center for Egyptology.

- Wen, Jing, (2018). "The Iconography of Family Members in Egypt's Elite Tombs of the Old Kingdom" Publicly Accessible PennDissertations, University of Pennsylvania.

-Wilkinson, R. H. 1992. Reading Egyptian art: A hieroglyphic guide to ancient Egyptian painting and sculpture. London. 